\title{
PENGARUH PEMBERIAN PUPUK CAIR URIN KAMBING ETAWA TERHADAP PERTUMBUHAN BAWANG MERAH
}

\author{
Nurlaila Sitepu \\ STKIP Yayasan Abdi Pendidikan Payakumbuh \\ lailastp1971@gmail.com
}

\begin{abstract}
ABSTRAK
Penelitian ini bertujuan untuk mengetahui pengaruh pemberian pupuk cair urin kambing Etawa terhadap pertumbuhan bawang merah (Allium ascalonicum L.). Metode penelitian yang digunakan adalah eksperimen dengan menggunakan Rancangan Acak Lengkap (RAL), terdiri dari 5 perlakuan dan 4 ulangan, yaitu perlakuan A (0 ml urin kambing/ polibag), perlakuan B (50 ml urin kambing/ polibag), perlakuan C (100 ml urin kambing / polibag), perlakuan D (150 urin kambing/ polibag), perlakuan E (200 ml/1 urin kambing/polibag). Pengamatan yang dilakukan terhadap tinggi tanaman bawang merah, barat basah umbi, jumlah umbi, dan diameter umbi. Hasil penelitian, $\mathrm{F}$ hitung $1.38<\mathrm{F}$ tabel $3.06(5 \%)$, berat basah $F$ hitung $0.8<\mathrm{F}$ tabel $3.06(5 \%)$, jumlah umbi $\mathrm{F}$ hitung $0.5<\mathrm{F}$ tabel 3.06 $(5 \%)$, dan diameter umbi bawang merah $\mathrm{F}_{\text {hitung }} 0.51<\mathrm{F}$ tabel 3.06 (5\%). Simpulan, pemberian pupuk cair urin kambing Etawa tidak berpengaruh terhadap tinggi tanaman bawang merah
\end{abstract}

Kata Kunci : urin kambing etawa, bawang merah

\begin{abstract}
This study aims to determine the effect of giving urine liquid fertilizer Etawa on the growth of shallots (Allium ascalonicum L.). The research method used was an experiment using a completely randomized design (CRD), consisting of 5 treatments and 4 replications, namely treatment $A(0 \mathrm{ml}$ of goat urine / polybag), treatment $B(50 \mathrm{ml}$ of goat urine / polybag), treatment $C(100 \mathrm{ml}$ of goat urine / polybag), D treatment (150 goat urine / polybag), E treatment $(200 \mathrm{ml} / \mathrm{l}$ goat urine / polybag). Observations were made on red onion plant height, wet western tubers, number of tubers, and tuber diameter. The results of the study, F count $1.38<F$ table $3.06(5 \%)$, wet weight $F$ count $0.8<F$ table $3.06(5 \%)$, number of tubers $F$ count $0.5<F$ table 3. $06(5 \%)$, and diameter of shallot bulbs $F$ count $0.51<F$ table $3.06(5 \%)$. Conclusion, the administration of liquid urine fertilizer Etawa goat did not affect the height of the shallot plant
\end{abstract}

Keywords: etawa goat urine, shallots

\section{PENDAHULUAN}

Bawang merah (Allium ascalonicum L.) merupakan salah satu komoditi hortikultura yang tergolong sayuran rempah. Sayuran rempah ini banyak 
dibutuhkan terutama sebagai pelengkap bumbu masakan guna menambah cita rasa dan kenikmatan makanan.

Budidaya bawang merah (Allium ascalonicum L.) perlu ditingkatkan mengingat permintaan konsumen dari waktu kewaktu terus meningkat, ini sejalan dengan pertambahan jumlah penduduk dan peningkatan daya belinya. Selain itu, dengan semakin berkembangnya industri makanan menyebabkan peningkatan kebutuhan terhadap bawang merah yang berperan sebagai salah satu bahan baku tambahan yang memiliki nilai ekonomis yang tinggi.

Keberhasilan tumbuh tanaman bawang merah selain dipengaruhi oleh faktor lingkungan dan kecukupan nutrisi bagi tanaman, tanaman responsif terhadap pertumbuhan termasuk penggunaan pupuk organik yang saat ini menjadi input yang paling direkomendasikan dalam rangka memperbaiki kualitas dan kesuburan lahan. Namun demikian sejauh ini variasi konsentrasi pupuk cair organik yang digunakan untuk budidaya bawang merah memerlukan kajian yang lebih efektifitasnya terutama terkait dengan upaya peningkatan dan produktifitas tanaman yang tinggi.

Pemupukan merupakan salah satu aspek yang dapat meningkatkan produktifitas.Saat ini ketersedian pupuk kimia terutama di desa masih terbatas.Pupuk buatan atau anorganik sulit didapat dan harganya yang tinggi, hal ini membuat produksi tidak seimbang dengan hasil yang diperoleh.Dengan demikian menyebabkan daya beli masyarakat tani terhadap pupuk menjadi berkurang, dan menyebabkan petani tidak banyak menerapkan budidaya yang baik untuk meningkatkan produksinya. Oleh karena itu diperlukan suatu usaha untuk mencari pupuk organik sebagai alternatif pengganti atau melengkapi pupuk anorganik yang digunakan petani bawang merah.

Keteredian urin kambing cukup melimpah dibeberapa daerah termasuk Jorong Piobang Kenagarian Piobang Kecamatan Payakumbuh Kabupaten Lima Puluh Kota sehingga dapat dimanfaatkan sebagai salah satu alternatif pemilihan pupuk organik. Pupuk kandang cair yang besasal dari urin ternak dapat bekerja lebih cepat karena mudah diserap oleh tanaman serta mengandung hormone tertentu yang dapat memacu pertumbuhan tanaman (Aisyah et al,. 2011).

Pupuk yang berasal dari urin kambing mempunyai keunggulan karena kandungan nutrisinya yang tinggi dibandingkan kotoran ternak padat. kotoran kambing mengandung $\mathrm{N}$ (Nitrogen) dan $\mathrm{K}$ (Kalium) dua kali lebih tinggi dibandingkan kotoran ternak padat, kandungan $\mathrm{K}$ (kalium) lima kali lebih banyak dari pada kotoran padat, kandungan $\mathrm{N}$ (Nitrogen) adalah dua sampai tiga kali lebih banyak.

Salah satu urin kambing yang bisa digunakan sebagai pupuk cair adalah urin kambing Etawa (Capra aegagrus hurcus) kerena urin kambing Etawa (Capra aegagrus hurcus) mengandung hormon alami golongan IAA, giberalin dan sitokinin lebih tinggi daripada urin ternak lainnya Prawoto dan Suprijadi, dalam Sari (2015). Limbah kambing Etawa (Capra aegagrus hircus) diolah menjadi 
pupuk organik cair (POC) untuk mengurangi limbah dan mengurangi biaya produksi pertanian akibat pembelian pupuk anorganik pabrik. Pupuk organik cair lebih mudah dimanfaatkan oleh tanaman karena unsur-unsur sudah terurai dan jumah tidak terlalu banyak sehingga manfaatnya lebih cepat terasa (Pancapalaga, dalam Sari, 2015).

Usaha untuk mengembalikan kesuburan tanah dengan memanfaatkan urin kambing untuk meningkatkan produksi tanaman. Juga telah dilakukan oleh Budhie, (2010) yang mengaplikasikan urin kambing Etawa terhadap pertumbuhan dan produksi tanaman pakan legum Indigofera sp. menunjukkan hasil bahwa pemberian pupuk organik cair (POC) berpengaruh sangat nyata terhadap pertumbuhan tanaman tinggi. Selanjutnya Sarah, (2016) juga pernah mengaplikasikan pupuk cair urin kambing pada tanaman lada (Piper nigrum L.), hasil penelitian menunjukkan bahwa pemberian pupuk cair urin kambing yang difermentasiterdapat pada perlakuan dengan konsentasi 100 $\mathrm{ml} / \mathrm{L}$ (A1) dan pada perlakuan dengan konsentrasi $200 \mathrm{ml} / \mathrm{L}$ (A2) yang menghasilkan pertumbuhan jumlah daun pada umur 15 hari setelah panen (HST), dan berat kering tanaman lada. Sehubungan dengan uraian diatas, maka telah dilakukan penelitian yang berjudul "Pengaruh Pemberian Pupuk Cair Urin Kambing Etawa (Capra aegagrus L.)terhadap Pertumbuhan Bawang Merah (Allium ascalonicum L.).

\section{METODE PENELITIAN}

Jenis penelitian yang digunakan adalah penelitian eksperimen, pengamatan dengan cara tanam langsung ke lapangan.Dilaksanakan di Jorong Piobang, Kenagarian Piobang, Kecamatan Payakumbuh Kabupaten Lima Puluh Kota, dari 22 April sampai 22 Juni 2018.

Bahan yang digunakan dalam Penelitian ini adalah: umbi bawang merah (Allium ascalonicum L), EM 4 (Effective Microorganisme), urin kambing Etawa, tanah, air, lengkuas, kunyit, jahe, gula merah, dan kencur.Alat yang digunakan dalam Penelitian ini adalah: polibag volume $5 \mathrm{~kg}$, ember, alat ukur, pisau, gayung, gunting, alat siram, cangkul, Parang, kertas, label, tali plastik, penunggal kecil, ayakan, timbangan, kamera, gelas ukur, seng, dan alat tulis.

Penelitian ini menggunakan Rancangna Acak Lengkap (RAL), Dengan 5 taraf perlakuan dan 4 ulangan sehingga terdapat 20 satuan Penelitian. Data hasil pengamatan dianalisis statistik dengan uji $\mathrm{F}$ pada taraf kepercayaan $1 \%$ dan 5\%) perlakuan konsentrasi pupuk organik cair urine kambing yaitu: Perlakuan A tanpa perlakuan, perlakuan B pemberian urin kambing dengan dosis $50 \mathrm{ml} / 5 \mathrm{~kg}$ tanah humus, perlakuan $\mathrm{C}$ pemberian urin kambing dengan dosis $100 \mathrm{ml} / 5 \mathrm{~kg}$ tanah humus, perlakuan Dpemberian urin kambing dengan dosis $150 \mathrm{ml} / 5 \mathrm{~kg}$ tanah humus, perlakuan E pemberian urin kambing dengan dosis $200 \mathrm{ml} / 5 \mathrm{~kg}$ tanah humus. Langkah-langkah fermentasi urin kambing menurut Nanda (2016:28) adalah sebagai berikut: 
1. Pembuatan pupuk organik cair urin kambing yaitu dengan cara, gula merah sebanyak 1 (ons) yang dicairkan sebayak $100 \mathrm{ml}$ air, ditambahkanbahanbahan lengkuas, kunyit, jahe, dan kencur jumlah masing- masing bahan tersebut sebanyak 1 (ons) dan ditumbuk sampai halus.

2. Kemudian bahan tersebut dimasukkan ke dalam urin kambing yang telah ditampung tadi ke dalam ember, maksud penambahan bahan-bahan ini untuk menghilangkan bau urin ternak dan memberikan rasa yang tidak disukai hama.

3. Setelah itu dicampur EM 4 sebanyak $10 \mathrm{ml}$. EM4 ini berguna untuk fermentasi dan nantinya setelah jadi pupuk cair bisa menambah jumlah mikroba yang menguntungkan.

4. Kemudian setelah bahan tercampur semua dimasukkan kedalam jerigen dan ditutup rapat dengan plastik dan disimpan ditempat teduh dan tidak terpapar sinar matahari.

5. Fermentasi urin didiamkan selama 14 hari dan diaduk setiap hari dengan cara membolak-balikkan jerigen.

6. Setelah 14 hari pupuk cair sudah jadi kemudian disaring dan dapat digunakan.

Bibit berupa rimpang bawang merah yang berasal dari Alahan Panjang, yang dikeringkan selama 1 bulan.Sebelum bawang merah ditanam dipotong ujungnya sekitar sepertiga bagian. Tanah yang digunakan sebagai madia adalah tanah humus yang terlebih dahulu dibersihkan dari gulma, kemudian dikering anginkan dan diayak dengan menggunakan ayanakan untuk membebaskan tanah dari organisme pengganggu (hama tanah).

Label digunakan untuk memudahkan dalam pemberian perlakuan. Pemasangan label dilakukan sebelum pemberian perlakuan.Bibit yang telah dipersiapkan ditanam pada polybag yang telah diberi perlakuan.Bibit ditanamsecara mendatar dengan kedalaman $1 \mathrm{~cm}$.

Pemeliharaan tanaman meliputi: penyiraman, penyiagan, pemupukan dilakukan 2 kali,yaitu pada umur 2 minggu setelah tanam, pemupukan diulang pada umur 4 minggu setelah tanam dan dosis yang digunakan sama dangan perlakuan pertama. Parameter yang diamati adalah tinggi tanaman $(\mathrm{cm})$, berat basah umbi tiap polybag (gram) jumlah umbi, dandiameter umbi $(\mathrm{cm})$

\section{HASIL PENELITIAN}

Berdasarkan penelitian yang telah dilakukan maka diperoleh hasil sebagai berikut

\section{Tinggi Tanaman Bawang Merah}

Rata-rata tinggi tanaman bawang merah setelah 9 minggu perlakuan dapat dilihat pada Tabel 1 sebagai berikut: 
Tabel 1 Rata-Rata Tinggi Tanaman Bawang Merah (Allium ascalonicum L)

\begin{tabular}{cc}
\hline Perlakuan & Rata-rata Tinggi Bawang Merah (cm) \\
\hline A & 37,23 \\
B & 39,85 \\
C & 44,63 \\
D & 38,65 \\
E & 44,45 \\
\hline
\end{tabular}

Hasil pengamatan berat basah umbi tiap polybag tanaman bawang merah dilakukan setelah panen pada minggu ke 10.menunjukkan bahwa pemberian pupuk cair urin kambing Etawa memperlihatkan bahwa berat basah umbi bawang merah menunjukkan adanya perbadaan rata-rata berat basah umbi bawang merah yang dilakukan setelah 10 minggu. Rata-rata berat basah umbi bawang merah tiap polybag dapat dilihat pada Tabel 2 .

Tabel 2 : Rata-rata Berat Basah Umbi Bawang Merah

\begin{tabular}{cc}
\hline Perlakuan & Rata-rata berat basah umbi (gram) \\
\hline A & 45,0 \\
B & 65,0 \\
C & 65,0 \\
D & 50,0 \\
E & 67,5 \\
\hline
\end{tabular}

Hasil pengamatan jumlah umbi per rumpun bawang merah menunjukkan bahwa pemberian urin kambing Etawa memperlihatkan jumlah umbi bawang merah yang berbeda untuk setiap perlakuan yang dilakukan setelah 10 minggu.Rata-rata jumlah umbi bawang merah tiap polybag dapat dilihat pada Tabel 3.

Tabel 3 : Rata-rata Jumlah Umbi Bawang Merah

\begin{tabular}{cc}
\hline Perlakuan & Rata-rata jumlah umbi bawang merah (buah) \\
\hline A & 7 \\
B & 9 \\
C & 9 \\
D & 8 \\
E & 10 \\
\hline
\end{tabular}

Hasil pengamatan diameter umbi bawang merah setelah 10 menunjukkan bahwa pemberian urin kambing Etawa memperlihatkan diameter bawang merah yang berbeda untuk setiap perlakuan dapat dilihat pada tabel 4 . 
Tabel 4: Rata-rata Diameter umbi bawang merah

\begin{tabular}{cc}
\hline Perlakuan & Rata-rata diameter umbi bawang merah $\mathbf{( c m )}$ \\
\hline A & 1,61 \\
B & 1,94 \\
C & 1,88 \\
D & 1,74 \\
E & 1,98 \\
\hline
\end{tabular}

\section{PEMBAHASAN}

\section{Tinggi Tanaman}

Dari Tabel 1 dapat dilihat bahwa rata-rata pertumbuhan tinggi tanaman bawang merah yang dilakukan setelah 9 minggu menunjukkan adanya perbadaan tinggi tanaman bawang merah. Data tinggi tanaman bawang merah selama 9 minggu Perlakuan C (100 ml/l urin kambing) merupakan yang tertinggi, yakni $44.63 \mathrm{~cm}$, diikuti dengan perlakuan E $200 \mathrm{ml} / 1$ urin kambing yaitu, $44.45 \mathrm{~cm}$, B $50 \mathrm{ml} / 1$ urin kambing yakni 39.85, lalu D $150 \mathrm{ml} / 1$ urin kambing yakni 38.65 dan A (Kontrol) dengan rata-rata pertambahan tinggi yaitu 37.23. Rata-rata pertambahan tinggi tanaman yang terendah yaitu tanaman yang tidak diberi perlakuan pupuk cair urin kambing A (Kontrol) dengan tinggi $37.23 \mathrm{~cm}$.

Hal ini disebabkan oleh dosis yang diberikan pada perlakuan $\mathrm{C}$ cukup untuk meningkatkan pertambahan tinggi tanaman bawang merah.Diduga karena urin kambing Etawa mengandung unsur hara yang dibutuhkan oleh tanaman bawang merah, salah satu unsurnya adalah nitrogen.Unsur hara yang terdapat dalam urin kambing Etawa yaitu nitrogen, fosfor dan kalium.Peningkatan tinggi tanaman ini disebabkan ketersediaan unsur hara terutama unsur hara $\mathrm{N}$ yang sangat diperlukan tanaman dalam mamacu pertumbuhan vegetatifnya.

Menurut Lingga dan Marsono dalam Kurniawan (2017) nitrogen merupakan komponen penyusun asam amino, protein dan pembentuk protoplasma sel yang dapat berfungsi dalam merangsang pertambahan tinggi tanaman, selain itu dalam urin kambing Etawa (Capra aegagrus hurcus L.), Menurut Prawoto dan Suprijadji dalam Fahmi (2018) menyatakan bahwa urin kambing memiliki hormon alami golongan IAA, giberelin, dan sitokinin lebih tinggi dari pada urin ternak lain Kadar giberelin yang terkandung dalam urin kambing 938 ppm, auksin 356 ppm.

IAA ( Indole Acetil Acid) adalah salah satu kandungan zat perangsang tumbuh yang dapat mempengaruhi pembentukan jaringan berbagai organ maupun sistem organ tanaman diantaranya merangsang perkembangan akar, tunas, meningkatkan proses fisiologi tanaman dan meningkatkan penyerapan hara Lingga dalam Priambono (2015) 


\section{Berat Basah Umbi}

Hasil pengamatan berat basah umbi tiap polybag tanaman bawang merah dilakukan setelah panen pada minggu ke 10.menunjukkan bahwa pemberian pupuk cair urin kambing Etawa memperlihatkan bahwa berat basah umbi bawang merah menunjukkan adanya perbadaan rata-rata berat basah umbi bawang merah yang dilakukan setelah 10 minggu. Rata-rata berat basah umbi bawang merah tiap polybag dapat dilihat pada Tabel 2 .

Pada Tabel 2 menunjukkan bahwa pemberian pupuk cair urin kambing Etawa menunjukkan perbedaan rata-rata berat basah umbi.Data berat basah untuk tiap bawang merah untuk tiap minggu selama 10 minggu perlakuan dilihat pada lampiran 3 halaman 74. Rata-rata berat basah umbi tertinggi adalah perlakuan $\mathrm{E}$ yaitu dengan pemberian urin kambing $200 \mathrm{ml}$ urin kambing Etawa menghasilkan nilai rata-rata yang paling tinggi yakni 67,5 gram dibandingkan dengan perlakuan yang lainnya. Sedangkan perlakuan A merupakan perlakuan dengan rata-rata berat basah umbi terendah yakni 45 gram, lalu diikuti oleh perlakuan B, perlakuan $\mathrm{C}$ yakni dengan rata- rata yang sama yakni 65 gram, sedangkan perlakuan D yakni dengan rata-rata 50 gram.

Menurut Direktorat Jenderal Bina Produksi Holtikultural dalam Susanti (2011), bawang merah akan menghasilkan umbi yang baik jika air berada dalam kapasitas lapang dari sejak pertumbuhan tanaman sampai pembentukan umbi, sebaliknya jika air dalam keadaan tergenang maka pertumbuhan juga terhambat, karena akar kekurangan oksigen. Jumlah umbi yang paling sedikit terdapat pada A (0 $\mathrm{ml}$ ), karena urin kambing tidak diberikan pada media sehingga tidak terdapat unsur hara yang dibutuhkan oleh tanaman bawang merah untuk menunjang jumlah umbi.

\section{Jumlah Umbi}

Hasil pengamatan jumlah umbi per rumpun bawang merah menunjukkan bahwa pemberian urin kambing Etawa memperlihatkan jumlah umbi bawang merah yang berbeda untuk setiap perlakuan yang dilakukan setelah 10 minggu.Rata-rata jumlah umbi bawang merah tiap polybag dapat dilihat pada Tabel 3

Pada Tabel 3 menunjukkan bahwa pemberian urun kmbing Etawa memperlihatkan jumlah umbi bawang merah yang berbeda untuk setiap perlakuan.Pada perlakuan A diperoleh jumlah umbi dengan rata-rata umbi bawang merah paling rendah yakni 7.25 gram, sedangkan perlakuan E diperoleh rata-rata umbi bawang merah paling tinggi yakni 9.5 gram, lalu diikuti oleh perlakuan B, perlakuan $C$ dengan rata-rata jumlah umbi yang sama yakni 8.75 gram, sedangkan perlakuan D dengan rata-rata jumlah umbi yakni 7.75 gram.

Menurut Riyanto dalam Wati (2014) menyatakan bahwa kandungan N yang tinggi membuat tanaman lebih hijau sehingga proses fotosintesis dapat berjalan sempurna yang berpengaruh terhadap kualitas dan kuantitas hasil akhir 
panen. Kandungan unsur $\mathrm{N}$ yang lebih banyak akan merangsang tumbuhnya anakan sehingga akan diperoleh hasil panen dengan jumlah umbi yang lebih banyak karena faktor anakan berpengaruh terhadap jumlah umbi.

Unsur $\mathrm{N}$ dapat membuat tanaman lebih hijau karena banyak mengandung butir-butir hijau daun yang penting dalam proses fotosintesa dan dapat merangsang tumbuhnya anakan. Sedangkan menurut Sejtamidjaja dan Wirasmoko dalam Sepriani (2015) unsur hara N berperan dalam merangsang pertumbuhan vegetatif, sehingga semakin banyak $\mathrm{N}$ tersedia menunjukkan pertumbuhan vegetatif yang semakin baik, karena pertumbuhan vegetatif menyokong pertumbuhan generatif.

Semakin tinggi hasil fotosintesis maka semakin baik pula hasil tanaman. Hasil fotosintesis yang berupa karbohidrat akan diakumulasikan pada bagian generatif dan pada bawang merah akumulasi karbohidrat yang dihasilkan sebagian besar digunakan untuk pembentukan umbi. Pemberian kalium pada bawang merah mempengaruhi pertumbuhan, hasil dan kualitas umbi.Defisiensi kalium dapat menghambat pertumbuhan, penurunan ketahanan dari penyakit, dan menurunkan hasil bawang merah (Singh dan Verma, dalam Wati (2014).

\section{Diameter Umbi Bawang Merah}

Hasil pengamatan diameter umbi bawang merah setelah 10 menunjukkan bahwa pemberian urin kambing Etawa memperlihatkan diameter bawang merah yang berbeda untuk setiap perlakuan.. Perlakuan E dengan pemberian urin kambing $200 \mathrm{ml}$ merupakan perlakuan dengan rata-rata tertinggi yakni 1.98, sedangkan A (Kontrol ) merupakan perlakuan dengan rata-rata diameter terendah yakni sebesar 1.61.

Kemudian diikuti oleh perlakuan B memiliki nilai rata-rata diameter yaitu $1.94 \mathrm{~cm}$, perlakuan Perlakuan C memiliki nilai rata- rata yaitu $1.88 \mathrm{~cm}$, sedangkan perlakuan D memiliki nilai rata-rata 1.74.Rata-rata diameter umbi bawang merah dapat dilihat pada Tabel 4.

Pada Tabel 4 menunjukkan bahwa pemberian urin kambing Etawa memperlihatkan diameter bawang merah yang berbeda untuk setiap perlakuan. Perlakuan E dengan pemberian urin kambing $200 \mathrm{ml}$ merupakan perlakuan dengan rata-rata tertinggi yakni 1.98, sedangkan A (Kontrol) merupakan perlakuan dengan rata-rata diameter terendah yakni sebesar 1.61. Kemudian diikuti oleh perlakuan B memiliki nilai rata-rata diameter yaitu $1.94 \mathrm{~cm}$, perlakuan Perlakuan $\mathrm{C}$ memiliki nilai rata- rata yaitu $1.88 \mathrm{~cm}$, sedangkan perlakuan D memiliki nilai rata-rata 1.74 .

Hal ini menunjukkan bahwa pupuk organik dari urin kambing dapat mencukupi kebutuhan hara tanaman sehingga dapat mendukung proses metabolisme tanaman dan memberikan pengaruh yang baik bagi pertumbuhan dan perkembangan tanaman. Menurut Novizan dalam Nanda (2016) menyatakan bahwa Nitrogen dibutuhkan untuk membentuk senyawa penting seperti klorofil, 
asam nukleat dan enzim. Jika terjadi kekurangan Nitrogen, tanaman akan tumbuh lambat dan kerdil.

Ginting dalam Nanda (2016) menambahkan bahwa Nitrogen merupakan unsur hara utama yang pada umumnya sangat diperlukan tanaman untuk pembentukan dan pertumbuhan bagian-bagian vegetatif tanaman seperti daun, batang dan akar.) selain itu urin kambing juga mendandung hormon alami golongan IAA giberalin dan sitokinin, yang dapat bermanfaat bagi tanaman yaitu, giberalin berperan dalam merangsang perkembangan dan perkecambahan embrio, sedangkan sitokinin berperan dalam pembelahan sel (sitokinenis) (Aryulina dalam Putri, 2017).

\section{SIMPULAN}

Berdasarkan hasil penelitian tentang pengaruh pemberian pupuk cair urin kambing Etawa (Capra aegagrus hircus) terhadap pertumbuhan bawang merah (Allium ascalonicum L.) yang telah dilakukan dapat diambil kesimpulan sebagai berikut: 1) dosis C (100 ml/1 ) urin kambing Etawa (Capra aegagrus hircus) memberikan pengaruh terhadap tinggi bawang merah dengan rata-rata 44,63 cm,; 2) dosis E (200 ml/l) urin kambing Etawa (Capra aegagrus hircus) memberikan pengaruh terhadap berat basah umbi bawang merah dengan rata-rata 57,5; 3) dosis E (200 ml/l) urin kambing Etawa (Capra aegagrus hircus) memberikan pengaruh terhadap jumlah umbi dengan rata-rata 9,5; 4) dosis $\mathrm{E}(200 \mathrm{ml} / 1)$ urin kambing Etawa (Capra aegagrus hircus) memberikan pengaruh terhadap diameter umbi dengan rata-rata 1,98

\section{DAFTAR PUSTAKA}

Aisyah, S. Sunarlim, N \& Solfan, B. (2011). Pengaruh Urin Sapi Terfermentasi Dengan Dosis Dan Interval Pemberian Yang Berbeda Terhadap Pertumbuhan Tanaman Sawi (Brassia juncea L.). (Online), https://uinsuskaejornal Uin-suskaac..id [ 23 Februari 2018].

Budhie, D.D.S. (2010). Aplikasi Urin Kambing Peranakan Etawa Dan Nasa Sebagai Pupuk Organik Untuk Pamacu Pertumbuhan Dan Produksi Tanaman Pakan LegumIndigofera sp. Skripsi. Fakultas Peternakan IPB. http://repositori. ipb.ac.id.[6 Maret 2018].

Fahmi, M., N. (2018). Pengaruh Pemberian Urin Kambing dan Pupuk Bokashi Terhadap Pertumbuhan Bibit Kakao (Theobroma cacao L.) . https://journalfapertaur.ac.id, 5(1).

Kurniawan, E. Ginting, Z \& Nurjannah, P. (2017). Pemanfaatan Urin Kambing Pada Pembuatan Pupuk Organik Cair Terhadap Kualitas Unsur Hara Makro (NPK). Makalah disajikan dalam Seminar Nasional Dan Teknologi Jakarta, Jurusan Teknik Kimia, Fakultas Teknik, Universitas Malilkussaleh Kampus Bukit Indah, Muara Satu, Lhokseumawe, 1-2 November 2017, https://jurnal.umj.ac.id . [14 Maret 2018]. 
Nanda, Mardiana \& Pane. (2016). Pengaruh Pemberian Berbagai Konsentrasi Pupuk Organik Urin Kambing Terhadap Pertumbuhan dan Produksi Tanaman Jagung Manis (Zea mays saccharata Sturt). Agrotekma.Fakultas Pertanian, Universitas Medan Area, Indonesiahttp://ojs.uma.ac.id/index.php/agrotekma [ 20 Maret 2018].

Priambono, T., H. (2015).Pangaruh Pemberian Pupuk Organik Cair Hasil Fermentasi Daun Gamal, Sabut Kelapa, Batang Pisang, Bekatul, dan EM 4 Terhadap Pertumbuhan Tanaman Terung (Solonum melongena.)Skripsi.Yogyakarta: Program Studi Pendidikan Biologi Jurusan Pendidikan Matematika dan Ilmu Pengetahuan Alam Fakultas Keguruan dan Ilmu Pendidikan Universitas Sanata Darma, https://repository. usd.ac.id [ 21 Agustus 2018].

Putri, A., H. (2017). Pengaruh Berbagai Konsentrasi Pupuk Organik Cair (POC) Urin Sapi Terhadap Pertumbuhan Tanaman Bayam Hijau (Amaranthus TricolorL.) Skripsi.Program Studi Pendidikan Biologi Jurusan Pendidikan Matematika Dan Ilmu Pengetahuan Alam Fakultas Keguruan Dan Ilmu Pendidikan Universitas Sanata Dharma Yogyakarta.Tidak diterbitkan.

Sari, R. (2015). Pemanfaatan Limbah Ternak Kambing Etawa sebagai Bahan Pupuk Organik Cair untuk Budi Daya Baby Corn. Jurusan Biologi, Fakultas Matematika dan Ilmu Pengetahuan Alam Universitas Negeri Surabaya. LenteraBio, 3(2) https://e-jounal.unesa ac.id. [23 April 2018]

Sarah, Rahmatan \& Supriatno,(2016). PengaruhPemberian Berbagai Konsentrasi Urin Kambing Yang Difermentasi Terhadap Pertumbuhan Vegetatif Lada (Piper nigrum L.) Jurnal IlmiahMahasiswa Pendidikan Biologi, Program Studi Pendidikan Biologi FKIP Unsyiah, (Online), 1(1) https://journalunsyiah.ac.id [3 Januari 2018].

Susanti, S. (2011).Pengaruh Pemberian Pupuk Cair Urin Sapi (Bos sp.) Terhadap Produksi Bawang Merah ( Allium ascalonicum L.) Skripsi . Tidak diterbitkan. STKIP Abdi Pendidikan Payakumbuh: Payakumbuh.

Sepriani. Y, Dorliana, K \& Sihaloho, N. (2015). Pengaruh Pupuk Organik Cair Urin Domba Terhadap Pertumbuhan Dan Produksi Tanaman Kangkung (Ipomoes reptans )". https://journal agroplasma(STIPER), 3(2).

Wati, Y,T, Nurlaelih, E,E \& Sontoso, M. (2014). Pengaruh Aplikasi Biourin Pada Pertumbuhan Dan Hasil Tanaman Bawang Merah (Allium ascalonicum L.). Journal Produksi Tanaman, 2(8) 